\title{
Evaluation of College Students' Employment Quality Based on Analytic Hierarchy Process
}

\author{
Mian Fu' ${ }^{1}$, Dan dan Wang ${ }^{1}$ \\ ${ }^{1}$ Business School, Xinhua University of Anhui Province Hefei, China
}

\begin{abstract}
The employment situation of college graduates is directly related to the future development of college students, affects the role of talents in our socialist modernization construction, and relates to social harmony and stability. Taking the employment quality evaluation of college students as the research object, the paper constructs the employment quality evaluation model of graduates by establishing the evaluation index system. Through the application of AHP and the evaluation model, the employment quality of the graduates of a university in 2018 is evaluated. According to the evaluation results, it is concluded that the quality of employment should be improved from three aspects: strengthening employment guidance education, strengthening professional practice learning and improving students' comprehensive quality.
\end{abstract}

\section{INTRODUCTION}

With the expansion of college enrollment, the number of college graduates is also increasing rapidly every year. According to statistics, the total number of college graduates in China was 1.07 million in 2001, 6.1 million in 2010 and 8.2 million in 2018. The employment situation of college graduates is directly related to the future development of college students, affects the role of talents in our socialist modernization construction, and relates to social harmony and stability. Pay attention to the employment quality of college graduates, study the key indicators that affect the employment quality of college students, select appropriate evaluation methods to evaluate them, get the evaluation results of the employment quality of graduates, and put forward reasonable suggestions to improve the employment quality of colleges, which is of great significance to improve the employment quality of college students $[1,2]$.

General secretary $\mathrm{Xi}$ Jinping pointed out that "employment is the greatest livelihood". College graduates, a large group of young people, are an important part of the annual new employment. The evaluation results of the employment quality of college graduates can provide constructive suggestions on promoting economic development, building a harmonious society and enhancing national competitiveness.

For the government, the statistics and analysis of the evaluation results of college graduates' employment quality is the basic guarantee for the government functional departments to issue employment guidance, policies and measures, which helps to promote the healthy development of higher education; it can quickly catch the attention of the public media, strengthen the social supervision and guarantee mechanism, and establish and improve the evaluation system of college graduates' employment.

As far as colleges and universities are concerned, the evaluation of graduates' employment quality can promote colleges and universities to reform teaching methods, improve teaching quality, modify and adjust specialty construction according to social needs, cultivate professionals meeting social needs, and promote the construction of "first-class universities and first-class disciplines".

\section{THE CONSTRUCTION OF THE EVALUATION INDEX SYSTEM OF COLLEGE STUDENTS' EMPLOYMENT QUALITY}

\subsection{The Basic Principles of Constructing Evaluation Index System}

In order to make the evaluation index more representative, theoretical and effective, we should pay attention to the following principles in the process of constructing the evaluation index system:

(1) Principle of pertinence

The purpose of this paper is to find out the key factors affecting the quality of employment through the analysis of the results of the evaluation, so as to provide decisionmaking basis for universities to make enrollment plans and major settings.

(2) Principle of combination of qualitative and quantitative

In order to ensure the rationality and effectiveness of the employment quality evaluation of college students, we should not use qualitative or quantitative indicators alone, but we need to combine qualitative and quantitative

*fm15395112646@126.com, wangdandan@sina.com 
indicators to reflect the employment quality comprehensively and accurately. At the same time, in order to make the evaluation carry out smoothly, the selected qualitative indicators are easy to quantify.

(3) Principle of operability

The operability and feasibility of the indicators should be considered when selecting the evaluation indicators, and the non operability indicators can not be considered to ensure that the evaluation is easy to implement.

(4) Principle of independence

Independence means that the same level of indicators can not exist cross situation, otherwise it will affect the weight of indicators and the accuracy of evaluation.

\subsection{The Construction of Evaluation Index System}

According to the employment data and survey data collected in the early stage, combined with the actual situation of colleges and universities, starting from the satisfaction of graduates, society and employers, three secondary indicators and 12 tertiary indicators are selected to form the evaluation index system[3,4], as shown in Figure 1.

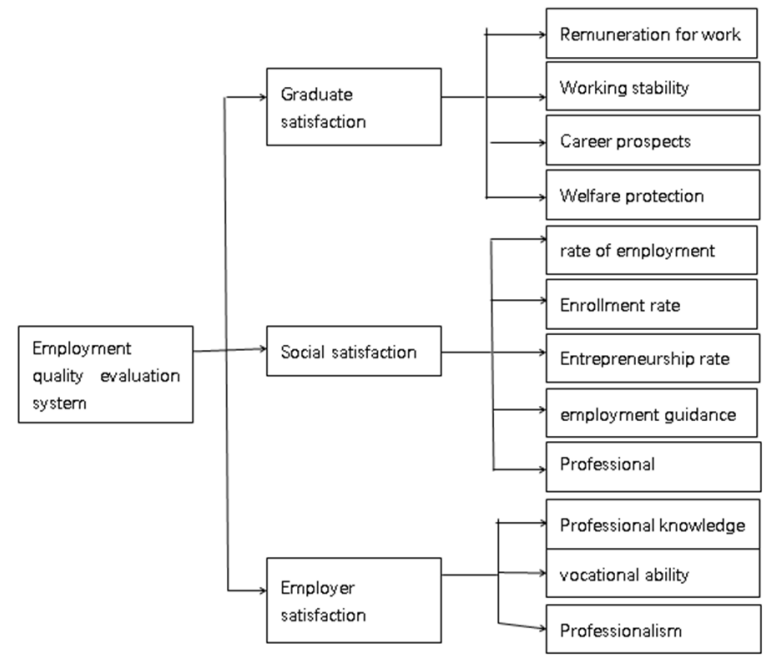

Fig 1. The evaluation index system of College Students' Employment Quality

(1) Graduate satisfaction

Graduate satisfaction refers to the degree of coincidence between working conditions and graduates' expectations, including: salary, job stability (whether labor contract is signed), career development prospects (whether the unit provides a clear career development channel), welfare (five insurances and one fund, welfare project), etc.

Labor remuneration refers to all kinds of income obtained by workers engaged in production activities. It includes the monetary and material wages from various sources, that is, the wage remuneration paid by the unit to the individual laborer in the form of wages, welfare and other forms from the cost, expense or profit, as well as the various labor remuneration obtained by the individual and other laborer through participating in production activities.

The meaning of "stability" lies in stability, not in more or faster. He is a kind of slow work out of the performance, such work only suitable for people who like plain life or don't like the competition is too fierce, in the survival is still leisurely. It will not lose its security on a large scale, and it will not lose its value quickly in the corresponding period of time.

Career development is a kind of planning used by an organization to help employees acquire the skills and knowledge needed for their current and future jobs. In fact, career development is the development training, education and other activities of knowledge, ability and technology for enterprise human resources.

Welfare treatment generally refers to the labor security and social security stipulated by the current labor law. The current welfare treatment refers to the non cash form of remuneration adopted by enterprises in order to retain and motivate employees. Therefore, the biggest difference between the welfare listed in this system and the allowance is that the welfare is non cash form of remuneration, while the allowance is paid in cash.

(2) Social satisfaction

Social satisfaction refers to the degree of satisfaction of the public to the employment situation of graduates, including: employment rate, enrollment rate, employment guidance, professional consistency, entrepreneurship rate, etc.

The employment rate is an index reflecting the employment degree of labor force. It refers to the percentage of employed persons in the sum of employed persons and unemployed persons. It reflects the proportion of all the labor force that may participate in social labor. In a certain period, the more employed or the less unemployed people are, the higher the employment rate is, and vice versa.

The enrollment rate refers to the percentage of the number of students entering school and the number of graduates in the grade. It is an important standard to reflect the educational development level of a region and to measure the educational quality of schools of the same level, but it is not the only standard.

Employment guidance is a consultation and guidance process in which professional guidance institutions help job seekers to determine their career direction, choose their careers, prepare for employment and seek career development. As an important social activity, employment guidance first appeared in European and American countries. It is the product of social efforts to solve the employment problem after a series of social contradictions caused by economic development, career differentiation and technological progress in western countries.

Professional consistency refers to the fact that a candidate's University major needs are consistent with or similar to the applied post discipline.

(3) Employer satisfaction

Employer satisfaction refers to the degree of acceptance of graduates' quality and work status by the employer, including: professional knowledge (basic, professional, industrial knowledge, etc.), professional ability (management, communication, innovation ability, etc.), professional accomplishment (attitude, quality, spiritual cultivation, etc.).

Professional knowledge is the basic knowledge of a certain occupation. The structure of professional 
knowledge refers to the knowledge system including basic knowledge, professional knowledge, humanities and science and technology literacy.

Occupational ability is a combination of various abilities for people to engage in a certain occupation. Professional competence mainly includes three basic elements: one is the ability that must be possessed in order to be competent for a specific occupation, which is manifested as the qualification; the other is the professional quality that is displayed after entering the workplace; the third is the career management ability that is possessed after starting the career.

Professional quality is a code of conduct that human beings need to abide by in social activities. The sum of individual behavior constitutes their own professionalism, which is the connotation and the external representation of individual behavior. "Professional belief" is the core of professional quality. "Professional knowledge and skills" is the professional knowledge and ability that a good job should have. "Professional behavior habit", professional quality is a kind of comprehensive quality in the workplace, which is formed through long-term learning, change and finally become a habit.

\section{EVALUATION OF EMPLOYMENT QUALITY of COLLEGE STUDENTS}

\subsection{Employment Quality Evaluation Model}

The process of College Students' employment quality evaluation is as follows: firstly, according to college students' employment data and expert opinions and other factors, establish the employment quality evaluation index system; Secondly, invite a certain number of graduates, social personages and employers, respectively give a certain weight, anonymously score each evaluation index according to the degree of importance, and use the analytic hierarchy process to calculate 12 three indexes. Thirdly, according to the relevant data of college graduates collected by the department of education, we score each index, which is expressed by the 100 point system. Finally, we calculate the comprehensive score of each subject of the evaluated university through the weighted sum of the weight and the evaluation score.

\subsection{Weight Determination of Evaluation Index Based on Analytic Hierarchy Process}

Analytic hierarchy process (AHP) is an operational research theory put forward by Professor Saaty of Pittsburgh University in the 1970s. It is an analytical method based on hierarchical weight decision. Analytic hierarchy process (AHP) is suitable for solving multiobjective and unstructured complex decision-making problems. The basic principle is: to hierarchize a complex problem, use less quantitative information to mathematicize the process, combine quantitative analysis with qualitative analysis, compare the indicators of the same level, establish a comparison matrix, judge its contribution rate to the indicators of the previous level, and so on through comparative analysis of each layer, the weight value of each index can be obtained.

When using analytic hierarchy process to assign the index weight in the evaluation model, it can be roughly divided into the following steps[5]:

(1) The complex problems are layered, and the hierarchical structure model is established

Firstly, the related factors of complex objective problems are decomposed into two-level index and threelevel index, which are called objective layer, criterion layer and index layer respectively.

(2) Establishment of contrast judgment matrix

When determining the importance of each index at each level, we need to use the consistent matrix method proposed by Saaty et al. Here, we use two indexes to compare with each other, rather than comparing all indexes together. The comparison judgment matrix represents the comparison of the relative importance of an index at the previous level, and the element aij in the comparison judgment matrix generally uses Saaty's 1-9 scale method.

(3) Calculate the weight vector and check the consistency

The eigenvector and the largest eigenvalue of each comparison judgment matrix are calculated, and the consistency index, consistency ratio and random consistency index are used for consistency test. If the consistency test is passed, the eigenvector is the weight vector; if the consistency test is not passed, the contrast judgment matrix needs to be reestablished to test the consistency ratio of the matrix, which can determine whether the index weight result calculated by AHP is reasonable.

(4) Calculate the weight of each index

There are two methods to calculate the weight of comparative judgment matrix: sum method and root method, namely standard column average method and geometric average method. In this paper, the standard column average method is used to calculate the weight value of each index.

\section{A CASE STUDY ON THE EVALUATION OF COLLEGES STUDENTS' EMPLOYMENT QUALITY}

Taking a university in Anhui Province as an example, the employment quality of university graduates in 2018 is evaluated. Firstly, the weight of the employment quality evaluation index of college students in Figure 1 is determined by AHP. In order to determine the index weight reasonably, an expert group of 40 graduates, social persons and employing units is invited to evaluate the employment quality independently. According to the weight of 0.4 of graduates and employers and 0.2 of social persons, the research is conducted. The evaluation indexes of employment quality are analyzed and compared, the evaluation indexes are classified anonymously according to the importance degree, and the judgment matrix of each level is obtained. Finally, the weight results are obtained by using Yaahp software of AHP, and the weighted 
comprehensive scores are calculated for all the results. The results are shown in Table 1.

Table1. Evaluation index weight of College Students' Employment Quality

\begin{tabular}{|c|c|c|c|}
\hline index & weight & index & weight \\
\hline Remuneration & 0.1385 & $\begin{array}{c}\text { Entrepreneurship } \\
\text { rate }\end{array}$ & 0.0632 \\
\hline stability & 0.0396 & $\begin{array}{c}\text { employment } \\
\text { guidance }\end{array}$ & 0.0834 \\
\hline $\begin{array}{c}\text { Career } \\
\text { prospects }\end{array}$ & 0.1587 & $\begin{array}{c}\text { Professional } \\
\text { consistency }\end{array}$ & 0.0689 \\
\hline $\begin{array}{c}\text { Welfare } \\
\text { protection }\end{array}$ & 0.0898 & $\begin{array}{c}\text { Professional } \\
\text { knowledge }\end{array}$ & 0.0446 \\
\hline $\begin{array}{c}\text { rate of } \\
\text { employment }\end{array}$ & 0.0712 & vocational ability & 0.125 \\
\hline Enrollment rate & 0.0635 & Professionalism & 0.0536 \\
\hline
\end{tabular}

According to the employment data of a university in Anhui Province collected by the Ministry of education in 2018, the indicators are scored, and then the comprehensive scores of each subject are calculated by using the employment quality evaluation model of university graduates, as shown in Table 2.

Table2. comprehensive score of evaluation specialty

\begin{tabular}{|c|c|c|c|}
\hline major & score & major & score \\
\hline $\begin{array}{c}\text { Computer science and } \\
\text { technology }\end{array}$ & 85.24 & economics & 69.56 \\
\hline $\begin{array}{c}\text { electronic } \\
\text { information } \\
\text { engineering }\end{array}$ & 82.45 & $\begin{array}{c}\text { tourism } \\
\text { management }\end{array}$ & 67.67 \\
\hline $\begin{array}{c}\text { business } \\
\text { administration }\end{array}$ & 80.23 & $\begin{array}{c}\text { civil } \\
\text { engineering }\end{array}$ & 63.43 \\
\hline English & 78.65 & humanity & 56.34 \\
\hline $\begin{array}{c}\text { communication } \\
\text { engineering }\end{array}$ & 74.89 & French & 43.54 \\
\hline Biotechnology & 72.98 & agronomy & 32.12 \\
\hline
\end{tabular}

According to the overall score of employment quality, the scores of computer science and technology, electronic information technology and business administration are higher, and the overall employment quality is better; the scores of humanities, French and agronomy are the lowest, and the employment quality is not ideal. For the subjects with unsatisfactory scores, the scores of professional consistency, professional knowledge and employment guidance are low from the index data. Therefore, in order to improve the overall employment quality, we need to strengthen the employment guidance education, strengthen the professional practice learning and improve the comprehensive quality of students.

\section{CONCLUSION}

Based on the characteristics of the existing employment data and evaluation needs of university graduates, 12 specific index factors are selected to establish the evaluation model of graduates' employment quality. According to the evaluation model, taking the major as the evaluation unit, the employment quality of the 2018 undergraduate graduates of a university in Anhui Province is evaluated through the application of AHP; According to the evaluation results, the employment quality of the university is improved. The paper also gives some suggestions on the quality of employment of subjects with unsatisfactory scores.

\section{ACKNOWLEDGEMENT}

This work was supported by Anhui Xinhua university comprehensive reform pilot project of logistics management under Grant No.2016zy068 and 2018 university level scientific research project of Quality Education Research Center for college students of Anhui Xinhua University under Grant No.IFQE201819 and 2019 Anhui University Humanities and social sciences research project under Grant No.SK2019A0728. The corresponding author of the article is Wang Dan-dan.

\section{REFENCES}

1. Huang Hong. Research on supplier evaluation index system based on analytic hierarchy process [J]. Journal of Qinzhou University, 2017 (10): 37-42

2. Chen $\mathrm{Xi}$. The evaluation of the quality of the initial employment of college students and the influencing factors[D].Wuhan:Huazhong Agricultural University, June 1, 2011

3. Yang Heqing, Li Jia. Establishment and application of the evaluation index system for the employment quality of university graduates [J]. Chinese Journal of talents. 2007(15)

4. Feng Qingyuan. Research on employment quality evaluation system of higher vocational graduates [J]. Contemporary vocational education. 2010 (05): 18-23

5. Qiu Li. Construction of logistics distribution service quality evaluation system under B2C mode based on fuzzy analytic hierarchy process $[\mathrm{J}]$. Logistics science and technology, 2017 (6): 6-11 